\title{
1. Introduction to the EU enforcement system and the goals of the Damages Directive
}

\section{A THE ENFORCEMENT OF EU COMPETITION LAW}

The European competition rules are contained in Articles 101 and 102 of the Treaty on the Functioning of the European Union (TFEU). The enforcement system in Europe is a dual system consisting of public and private enforcement. It is also dual to the extent that there exist public enforcement authorities on the national and European levels. While 'public enforcement' means that competition rules are applied by the European Commission (Commission), national competition authorities (NCA), or courts, 'private enforcement' refers to the application of competition rules in disputes between private parties. In contrast to the US, where competition law is predominantly enforced through private actions, the EU's primary method for enforcing the competition rules is through public enforcement. The Commission and the NCA thereby enjoy a set of enforcement powers which go beyond the fact-gathering rights of private parties.

\section{The enforcement powers of the European Commission}

The powers that enable the Commission to enforce the EU competition rules are contained in Regulation 1/2003, which took effect on 1 May 2004. ${ }^{1}$ Prior to Regulation 1/2003, agreements that fell under the prohibition of Article 101(1) TFEU could only be exempted either if they fell within the block exemption regulation, an option that is still possible under the current regime, or through an individual exemption from the Commission. The Commission was the central and sole authority which had the power to declare Article 101(1) inap-

\footnotetext{
1 Regulation No. 1/2003 of 16 December 2002 on the implementation of the rules on competition laid down in Articles 81 and 82 of the Treaty [2003] OJ L001/01.
} 
plicable pursuant to Article 101(3). ${ }^{2}$ The fundamental change brought about by Regulation 1/2003 was to move towards a decentralised enforcement regime and to declare Article 101(3) directly applicable. It was accompanied by several Notices which established the mechanisms for cooperation between the Commission and the NCAs and institutions. ${ }^{3}$ The Commission combines legislative, executive, and judicial powers which, despite having been criticised by many commentators, remained unaffected by the decentralisation and modernisation. ${ }^{4}$ It continues to enjoy broad powers; it may commence an investigation into an alleged competition infringement; and enjoys a discretion in setting priorities when enforcing competition rules. The Commission's administrative procedure is split into two stages: the preliminary investigation stage and the 'adversarial' stage. ${ }^{5}$ The preliminary investigation lasts until the Commission issues the Statement of Objection (SO) in which the Commission outlines its reasoning of the alleged infringement. The move to the adversarial stage entails the initiation of a proceeding, a formal act by which the Commission indicates its intention to adopt a decision under Regulation 1/2003.

The Commission's investigative powers during the preliminary investigation stage are entailed in Articles 18-21 of Regulation 1/2003. Article 18 sets out the Commission's right to send requests for information (either as simple requests or by decision). In addition to request vis-à-vis undertakings, the Commission may also request information from Member States and NCAs. Although there exists no duty to comply with simple requests for information, undertakings providing incorrect or misleading information can be fined under Article 23(1)(a). However, there is an incentive for undertakings to cooperate with the Commission as this can lead to a reduced fine in the event that the investigation results in an infringement decision. ${ }^{6}$ Undertakings are required to provide 'all necessary information' requested by the Commission (Article 18(1)). The restriction of the disclosure obligation to necessary information requires the Commission to comply with the principle of proportionality and

2 Article 9(1) of Regulation 17/62 implementing Articles 85 and 86 of the Treaty [1962] OJ 13/204.

3 Commission Notice on cooperation within the network of competition authorities [2004] OJ C101/43; Commission Notice on cooperation between the Commission and the courts of the EU Member States in the application of Articles 81 and 82 [2004] OJ C101/54.

${ }_{4}$ See for example Wouter P. J. Wils, 'The Combination of the Investigative and Prosecutorial Function and the Adjudicative Function in EC Antitrust Enforcement: A Legal and Economic Analysis' (2004) 27 World Competition 201.

5 Alison Jones, Brenda Sufrin and Niamh Dunne, EU Competition Law: Text, Cases, and Materials (7th edn, Oxford University Press 2019) 881.

6 See Part IV, Chapter 7, B.II for a more detailed discussion on mitigating factors taken into account for the setting of fines. 
must be interpreted as intended to protect against arbitrary or disproportionate interference by public authorities with the sphere of private activity. ${ }^{7}$ The Commission may therefore only request information that can reasonably be considered necessary to detect the (alleged) infringement. ${ }^{8}$ In other words, the wording prohibits 'fishing exhibitions' by the Commission. Article 20 empowers the Commission to carry out inspections of undertakings at their premises, either based on a written authorisation (Article 20(3)) or a decision (Article 20(4)). ${ }^{9}$ For as long as the inspection is to be conducted based solely on a written authorisation, the undertaking is under no obligation to submit to the inspection. By contrast, an undertaking is required to submit an inspection ordered by a decision, commonly also referred to as 'dawn raids'. Since the inspections are carried out within the territories of Member States, the Commission relies on the assistance of national authorities and courts. The rules of cooperation between the Commission and national authorities are specified in Article 20(5) and (6). Article 20(5) empowers national authorities, in whose territory the inspection is to be conducted, to assist the Commission. The NCA's officials thereby enjoy the same powers as the Commission under Article 20. The Commission itself has no power to enforce its inspection decisions and has only a limited repertoire of enforcement measures at its disposal if a company only incompletely submits the requested documents or evades an inspection altogether. The enforcement of the Commission's inspection decision is therefore dependent upon the assistance of national authorities which is laid down in Article 20(6). If assistance requires authorisation from a judicial authority under national law, the NCA must obtain such authorisation (Article 20(7)). In Deutsche Bahn, the Court of Justice (CJEU) again clarified that the prohibition of so-called 'fishing exhibitions' also applies to inspections carried out by the Commission. ${ }^{10}$ It restricted the ability of the Commission to use evidence obtained by accident during an inspection that is outside the subject matter of the investigation. This does not mean that the Commission is barred entirely from initiating an inquiry to verify or supplement information that it happened to obtain during a previous investigation. ${ }^{11}$ The Commission is, however, prohibited from using such evidence if the discovery of that evidence was not fortuitous. In the case, the Commission had informed its agents about a second complaint against Deutsche Bahn before they carried out the inspec-

7 Joined Cases T-458/09 and T-171/10 Slovak Telekom a.s. v European Commission [2012] ECLI:EU:T:2012:145, para. 81.

8 Regulation No. 1/2003, recital 23.

9 Article 21 extends the Commission's powers to carry out inspections to private premises of the concerned undertaking's employees.

10 C-583/13 P Deutsche Bahn AG v Commission [2015] ECLI:EU:C:2015:404.

11 Deutsche Bahn (n. 10) para. 59. 
tion; the agents, in possession of that information, then also seized documents falling outside the scope of the inspection conducted at that time. ${ }^{12}$

Article 19 of Regulation 1/2003 empowers the Commission to conduct formal interviews with natural or legal persons if they consent to be interviewed. Article 3 of Regulation 773/2004 provides further rules on the procedure of the interviews, such as the obligation to state the legal basis and the purpose of the interview as well as the obligation to record the interview. ${ }^{13}$

The preliminary investigation ends when the Commission closes the investigation, proceeds with issuing a commitment decision, or opens a formal procedure for an infringement decision. Before the Commission can issue a decision, Article 27(1) requires the Commission to grant the undertaking subject to the proceeding 'the opportunity of being heard on the matters to which the Commission has taken objection'. According to Article 10(1) of Regulation 773/2004, the Commission must inform the parties in writing of the objections raised against them. ${ }^{14}$ The Commission satisfies the requirement by sending an $\mathrm{SO}$ in which it sets out the facts and the reasoning as to why the Commission considers that Article 101 or 102 is infringed. If the Commission intends to impose remedies, the SO must describe the remedy in detail, to allow the undertaking to defend itself; in particular it must state the factors which influence the amount of the fine.

Article 27(2) of Regulation 1/2003 gives the parties concerned in the investigation a right to access the Commission's file as part of their right to defend themselves against the Commission's case. ${ }^{15}$ The right to access the file also extends to the complainant whose complaint was rejected. ${ }^{16}$ The use of leniency corporate statements or settlement submissions contained in the Commission's file is restricted. As will be discussed in more detail in this book, the Damages Directive prohibits access to leniency statements for the purpose of claiming damages in an attempt to ensure the effectiveness of the leniency programme. ${ }^{17}$ In line with the Directive's objective, Article 16a of Regulation 773/2004 (as amended by Regulation 2015/1348) now prohibits the use of information gained from leniency corporate statements and set-

\footnotetext{
Deutsche Bahn (n. 10) para. 66.

C-413/14 Intel v Commission [2017] EU:C:2017:632, para. 86.

14 Regulation No. 773/2004 of 7 April 2004 relating to the conduct of proceedings by the Commission pursuant to Articles 81 and 82 of the EC Treaty [2004] OJ L123/18.

15 The procedure is regulated in more detail on the Commission Notice on the rules for access to the Commission file in cases pursuant to Articles 81 and 82 of the EC Treaty, Articles 53, 54 and 57 of the EEA Agreement and Council Regulation (EC) No. 139/2004 [2004] OJ C325/07, as amended by OJ C256/7.

16 Article 8 of Regulation 773/2004 (n. 14).

17 See Chapter 2, B.IV.
} 
tlement submissions for purposes other than the defence in Article 101 and 102 TFEU proceedings. Moreover, the right to access the information in the Commission's file is restricted to information that does not contain business secrets or other confidential information. ${ }^{18}$ In addition, access to the file can also be sought under Regulation 1049/2001 (Transparency Regulation). Article 2(1) of the Transparency Regulation grants any citizen of the Union, and any natural or legal person residing or having its registered office in a Member State, the right to access documents of the institutions, subject to the principles, conditions and limits defined in the Regulation. Such exceptions to the right of access are set out in Article 4, which in its subparagraph 1 provides an absolute prohibition of disclosure where the disclosure would undermine the protection of the public interest in specific areas and an individual's privacy rights; and in its subparagraphs 2 and 3 allows the disclosure only if there is an overriding public interest in the disclosure of the requested documents. The necessary weighing between the public interest in the disclosure and the interests protected under Article 4(2) and (3) are of particular significance in relation to the disclosure of leniency statements. The CJEU has accepted that a general presumption applies that the disclosure of documents in the Commission's file would undermine the protection of commercial interests of parties involved as well as the purpose of the investigations. ${ }^{19}$

The investigation ends with a final decision ordering the termination of the infringement or the finding of inapplicability of Articles 101 and 102 TFEU. In addition, the Commission may take interim measures before the Commission arrives at a final decision (Article 8). According to Article 7 of Regulation $1 / 2003$, the Commission may order the undertaking concerned to bring the established infringement to an end. In order to do so, Article 7(1) empowers the Commission to impose behavioural or structural remedies. By way of structural remedies, the Commission seeks to bring the infringement to an end through changes to the competitive structure of the relevant market. Because changes to the structure of an undertaking are particularly burdensome for the undertaking subject to the structural remedies, Regulation 1/2003 requires the Commission to observe the principle of proportionality when it imposes structural remedies. Structural remedies are the ultima ratio and 'should only be imposed either where there is no equally effective behavioural remedy or where any equally effective behavioural remedy would be more burdensome for the undertaking concerned than the structural remedy'. ${ }^{20}$ Furthermore,

\footnotetext{
18 Article 27(2) of Regulation 1/2003 and Article 16(1) Regulation 773/2004 (n. 14).

19 The weighing of interests in relation to the disclosure of leniency statements under the Transparency Regulation is explained further in Part III, Chapter 6, B.III.

20 Regulation $1 / 2003$, recital 12.
} 
Regulation 1/2003 states that changes to the structure of an undertaking 'would only be proportionate where there is a substantial risk of a lasting or repeated infringement that derives from the very structure of the undertaking' ${ }^{21}$ Behavioural remedies, on the other hand, address the infringement by requiring a specific conduct from the undertaking concerned; which, in cartel cases, can include the requirement to refrain from sharing sensitive information with other undertakings.

Article 9 of Regulation 1/2003 enables the Commission to adopt a decision whereby it makes binding the commitments offered by the undertaking to meet the Commission's concerns, without a finding of an infringement. However, such commitment decisions are not appropriate in cases where the Commission intends to impose a fine. ${ }^{22}$ In fact, the Commission does not apply the Article 9 procedure to secret cartels that fall under the leniency programme. ${ }^{23}$ Lastly, the Commission can terminate the investigation with a decision finding that Articles 101 and 102 TFEU are inapplicable to a particular agreement or practice (Article 10 of Regulation 1/2003). According to recital 14 , an inapplicability decision will only be issued in exceptional cases 'with a view of clarifying the law and ensuring its consistent application'. Thus, an inapplicability decision is not intended for the benefit of the parties subject to the investigation but, as stated in Article 10, when the public interest requires the declaration of inapplicability.

The Commission is empowered to impose fines on undertakings for substantive infringements of competition rules (Article 23(2)) and for procedural infringements (Article 23(1)). Fines for infringements of an undertaking during the Commission's proceeding, in particular for supplying incorrect or misleading information in response to a request for information, can reach up to 1 per cent of the undertaking's total turnover in the preceding business year (Article 23(1)). The Commission may also impose periodic penalty payments up to 5 per cent of the average daily turnover in the preceding business year in order to compel an undertaking to comply with the Commission's decision (Article 24).

The focus of this book lies on the Commission's power to impose fines for substantive infringements under Article 23(2). The Commission has the ability to sanction competition infringements committed either intentionally or negligently with a maximum fine of 10 per cent of the infringing undertak-

21 Ibid.

22 Regulation 1/2003, recital 13.

23 Commission Notice on best practices for the conduct of proceedings concerning Articles 101 and 102 TFEU [2011] OJ C308/06 para. 116. As will be explained in section $\mathrm{C}$ below, the analysis in this book focuses on the secret cartels. For that reason, the Article 9 procedure will not be discussed in further detail at this stage. 
ing's worldwide turnover in the preceding business year. The fine imposed by the Commission is not a criminal penalty ${ }^{24}$ and cannot be imposed on natural persons. For the purpose of setting the fine, Article 23(3) requires the Commission to have regard to both the gravity and the duration of the infringement. With the exception of providing a ceiling for the fine and the requirement to take into account the gravity and duration, Regulation 1/2003 provides no guidance in relation to the methodology of setting the fines. In particular, the Regulation does not specify how and whether the fine should ensure the deterrence of future competition infringement. However, the CJEU had already held in relation to the predecessor of Regulation $1 / 2003^{25}$ that in assessing the gravity of an infringement for the purpose of fixing the amount of the fine, the Commission must also ensure that its action has the necessary deterrent effect. ${ }^{26}$ Moreover, the CJEU clarified that turnover means the total turnover of the undertaking or the group and not solely of the entity that has committed the infringement. ${ }^{27}$ Over the years, the Commission has adopted guidelines in which it lays down its methods for setting fines. Part IV of this book discusses the Commission's methodology for setting fines in more detail.

A key instrument of the EU public enforcement regime to uncover cartels is the leniency programme. In 1996, the Commission for the first time published its Leniency Notice, ${ }^{28}$ which outlined the rules and procedure but did not yet grant full immunity from fines. Full immunity from fines for the undertaking uncovering the cartel was introduced with the amended Notice in $2002 .{ }^{29}$ The 2002 Notice was replaced by the 2006 Notice, which is still in force today. ${ }^{30}$ Under the leniency programme, immunity is granted to the first undertaking that submits sufficient evidence to enable the Commission to find an infringement or to conduct an Article 20(4) inspection. Undertakings that approach the Commission late and therefore do not qualify for immunity can still receive a reduction of the fine if they produce information of significant added value. The first leniency applicant approaching the Commission after the immunity

\section{Article 23(5).}

Regulation 17/62 (n. 2).

26 Cases C-100-103/80 Musique Diffusion française SA v Commission (Pioneer) [1983] EU:C:1983:158, para. 106.

27 Pioneer (n. 26) para. 119.

28 Commission Notice on the non-imposition or reduction of fines in cartel cases [1996] OJ C204/14.

29 Commission Notice on immunity from fines and reduction of fines in cartel cases [2002] OJ C45/3.

30 Commission Notice on immunity from fines and reduction of fines in cartel cases [2006] OJ C298/11. Provisions on the Commission's Leniency Programme were added to Regulation $773 / 2004$ (n. 14) (Article 4a) for the first time when it was amended in 2015. 
recipient that has met the conditions under the Leniency Notice qualifies for a 30-50 per cent reduction, the second in the queue, a 20-30 per cent reduction, and subsequent applicants, a reduction of up to 20 per cent. The EU leniency programme and its implications in the methodology for setting the fines are also discussed in Part IV of the book whereas Part III discusses the impact of private enforcement on the effectiveness of the EU leniency programme.

A similar instrument to enhance the effectiveness of cartel enforcement is the settlement procedure introduced in 2008 by way of an amendment of Regulation 773/2004. The procedure is set out in the Notice on the conduct of settlement procedures of the same year. ${ }^{31}$ Under the settlement procedure, the Commission can invite the undertakings concerned to reach an agreement. The Commission will then inform the parties about the evidence against them and the Commission's conclusion in respect of the infringement (duration, gravity, liability, and potential fine). Parties opting for a settlement procedure must then provide a settlement submission which must contain an acknowledgement in clear and unequivocal terms of the parties' liability for the infringement; an indication of the maximum amount of the fine the parties would accept; confirmation that the parties have been informed about the Commission's objections; confirmation that the parties will not request access to the file or request to be heard again in an oral hearing; and agree to the statement of objections and the final decision pursuant to Articles 7 and 23 of Regulation (EC) $1 / 2003 .{ }^{32}$ The advantage for the party agreeing to the settlement procedure is above all a 10 per cent reduction in the fine. The Notice states that the objective of the simplified settlement procedure is to 'allow the Commission to handle more cases with the same resources, thereby fostering the public interest in the Commission's delivery of effective and timely punishment, while increasing overall deterrence'. ${ }^{33}$

As will be explained in Chapter 2, both the leniency corporate statements and the settlement statements are prohibited from disclosure for the purpose of claiming damages.

\section{The enforcement powers of NCAs}

As explained above, Regulation 1/2003 changed the enforcement regime to a decentralised system in which NCAs play a much more significant role in the

31 Commission Notice on the conduct of settlement procedures in view of the adoption of Decisions pursuant to Article 7 and Article 23 of Council Regulation (EC) No. $1 / 2003$ in cartel cases [2008] OJ C167/1 which was subsequently amended in 2015 (C 256/02).

32 Settlement Notice (n. 31) para. 20.

33 Settlement Notice (n. 31) para. 1. 
enforcement of Articles 101 and 102 TFEU. This hybrid enforcement regime also requires more coordination between the Commission and the NCA for an effective enforcement of the competition rules. For example, as discussed before, the provisions on assistance by NCAs in Article 20(5) and (6) of Regulation 1/2003 illustrate the cooperation between the Commission and the NCAs. Together the Commission and NCAs form a network of enforcement authorities in the EU, the European Competition Network (ECN). Despite the cooperation between the Commission and NCAs in the ECN, the Commission still has the last say when it comes to interpreting the EU competition rules. In the Cooperation Notice, the Commission describes its central role in the application of the competition rules as having 'the ultimate but not the sole responsibility for developing policy and safeguarding consistency when it comes to the application of competition law' ${ }^{34}$ Article 11 of Regulation 1/2003 specifies the relationship between Commission and NCAs. It provides that the NCA must inform the Commission 30 days prior to the adoption of a decision applying Article 101 or Article 102 TFEU. The Commission may then submit written observations on the case or initiate its own proceeding (Article 11(6)) which results in the NCA losing its competence.

The main powers of NCAs when enforcing the EU competition rules are contained in Article 5 of Regulation 1/2003. The basic rule is that NCAs are empowered to apply Articles 101 and 102 TFEU to cases in their territory. In line with the Commission's powers, NCAs can require the undertakings concerned to bring an infringement to an end, order interim measures, accept commitments, and impose fines, periodic penalty payments or any other penalty that exists under national law. However, NCAs cannot declare the inapplicability of Articles 101 and 102 TFEU by way of a non-infringement decision. Recently, with the transposition of the ECN+ Directive, NCAs' rights to enforce the EU competition rules have experienced a boost. ${ }^{35}$ The ECN+ Directive's stated objective is to 'to ensure that NCAs have the guarantees of independence, resources, and enforcement and fining powers necessary to apply Articles 101 and 102 TFEU effectively'. ${ }^{36}$ In terms of the NCAs' rights, the ECN+ Directive provides for minimum harmonisation of rights, which are

34 Commission Notice on cooperation within the network of competition authorities [2004] OJ C101/43, para. 43.

35 Directive (EU) 2019/1 to empower the competition authorities of Member States to be more effective enforcers and to ensure the proper functioning on the internal market (ECN+ Directive) was signed into law on 11 December 2018 and published in the Official Journal of the European Union on 14 January 2019 OJ L11/3. According to Article 34 of the ECN+ Directive, Member States had to transpose the new provisions by 4 February 2021.

$36 \mathrm{ECN}+$ Directive, recital 3. 
modelled on the existing enforcement privileges of the Commission. To that end, the $\mathrm{ECN}+$ Directive to a large extent duplicates the information-gathering powers of the Commission in Regulation 1/2003. Member States must ensure that NCAs have the power to inspect business premises ${ }^{37}$ and other premises ${ }^{38}$ to issue requests for information, ${ }^{39}$ and to conduct interviews of representatives or natural persons. ${ }^{40}$ In parallel to the Commission, where the NCA finds an infringement, it has essentially the same powers as the Commission under Article 7 of Regulation 1/2003. ${ }^{41}$ In particular, the NCA can impose structural and behavioural remedies which need to satisfy the same proportionality requirement as required under Regulation 1/2003. Article 12 of the ECN+ Directive empowers NCAs to impose commitment decisions parallel to Article 9 of Regulation 1/2003. Article 11 mirrors the rules for interim measures in Article 8 of Regulation 1/2003.

Chapter V of the ECN+ Directive provides relatively detailed rules on the methodology for setting fines and periodic penalty payments. The ECN+ Directive's objective is to minimise divergent outcomes ${ }^{42}$ and to ensure that Member States set 'effective, proportionate and dissuasive fines' ${ }^{43}$ It is no surprise that the harmonised parameters for the setting of the fines are largely aligned to the Commission's powers and practice. For example, Member States must ensure that the ceiling for the maximum fine is at least 10 per cent of the total worldwide turnover of the undertaking concerned, but Member States are still allowed to exceed the 10 per cent ceiling (Article 15). Moreover, Member States must have regard to the gravity and duration of the infringement when setting the fine (Article 14(1)) 'in a way that ensures deterrence'. ${ }^{44}$ It also requires Member States to apply the European notion of undertaking to avoid companies being able to avoid fines through corporate restructurings. ${ }^{45}$

\footnotetext{
37 Article 6.

38 Article 7.

39 Article 8.

40 Article 9.

41 Article 10.

42 The Impact Assessment found that prior to the transposition of the harmonised rules, fines varied by up to 25 times depending on which authority was acting; see Impact Assessment accompanying the Proposal for a Directive of the European Parliament and of the Council to empower the competition authorities of the Member States to be more effective enforcers and to ensure the proper functioning of the internal market SWD(2017) 114, 20.

43 Article 13(1).

$44 \quad \mathrm{ECN}+$ Directive, recital 47.

45 Article 13(5). It will be discussed in more detail in Chapter 2I, section B.VII that the notion of undertaking applies universally in European law and in turn also in national damages actions resulting from an infringement of EU competition rules.
} 
The ECN+ Directive also seeks to harmonise the national leniency regimes throughout the EU. Each Member State has to implement a leniency programme; the framework of those national programmes is laid down in Chapter VI of the ECN+ Directive and in essence mirrors the Commission's leniency programme. According to the harmonised rules, the leniency programmes must grant immunity from fines to the first undertakings to disclose their participation in secret cartels with the exception of those undertakings that have taken steps to coerce other undertakings to join a secret cartel or to remain in it (Article 17). Undertakings that have not uncovered the secret cartel but nevertheless provide evidence with significant added value can qualify for a reduction of fines (Article 18). However, the Directive does not specify the level of reductions undertakings should be granted according to their position in the queue. Although the transposition of the new rules will undoubtedly generate more convergence among the leniency programmes, it will not lead to full harmonisation with the Commission's leniency programme. Moreover, the Commission's and NCAs' leniency programmes remain legally independent and - despite calls from practitioners and undertakings concerned ${ }^{46}$ - there still exists no one-stop shop for leniency applications. This means that an immunity recipient before the Commission or an NCA does not automatically also secure the same status before other NCAs. The leniency applicant must instead apply separately for leniency in each Member State that is potentially affected by the cartel. Thus, the applicant's place in the queues across Europe may vary significantly.

\section{Private enforcement of EU Commission law}

Private enforcement can take different forms, notably by declaring an agreement void because it violates Article 101 or 102 TFEU (competition law as a shield), injunctive reliefs, or damages actions (competition law as a sword). In contrast to public enforcement, where competition authorities investigate and make use of their extensive information-gathering powers to reveal and prove an infringement, private enforcement means that private parties must bring and prove the case before the national court with little or no investigatory rights. In the majority of private enforcement cases in Europe, plaintiffs therefore claim damages after the Commission or an NCA has found an infringement in order to rely on the competition authority's findings before the civil

46 Around the time the discussion about the proposal of the ECN+ Directive started, the CJEU held in $D H L$ that leniency applications to the Commission were not binding on NCAs, which meant that DHL lost its full immunity for part of the cartel in Italy (Case C-428/14 DHL Express v Autorità Garante della Concorrenza e del Mercato [2016] ECLI:EU:C:2016:27). 
courts (follow-on). In only a small number of cases, plaintiffs first request the court to establish the finding of an infringement before claiming compensation for potential damage (stand-alone).

Although the CJEU recognised as early as 2001 an individual's right to claim damages for loss caused to him by an infringement of the EU competition rules, ${ }^{47}$ up until 2014, damages actions were still relatively rare. ${ }^{48}$ In addition, the procedure for claiming damages is governed by national civil and procedural law. These laws can provide significant hurdles for victims to claim and prove their cases despite EU law requiring that Member States ensure that the right to claim damages for competition infringements takes full effect. ${ }^{49} \mathrm{In}$ that period, the actions for damages caused by competition infringements were concentrated in three Member States: Germany, the Netherlands, and the UK.

In 2014, a significant step was taken at the European level to foster private enforcement with the signing into law of Directive 2014/104/EU on certain rules governing actions for damages under national law for infringements of the competition law provisions of the Member States and of the European Union (the Directive). ${ }^{50}$ The Directive emphasises that the effectiveness of the competition enforcement regime requires the interaction of private enforcement actions under civil law and public enforcement by competition authorities. ${ }^{51}$ On the other hand, the Directive also recognises that, in line with previous case law of the CJEU, ${ }^{52}$ the full effectiveness of Articles 101 and 102 TFEU requires that anyone can claim compensation before national courts for harm caused to them by an infringement of those provisions. ${ }^{53}$ In the proposal for the Directive, the Commission expressly described the objectives of the Directive as two-fold: (i) optimising the interaction between public and private enforcement of competition law; and (ii) ensuring that victims of infringe-

47 Case C-453/ 99 Courage Ltd v Bernard Crehan [2001] ECLI:EU:C:2001:465, para. 26.

48 Report from the Commission to the European Parliament and the Council on the implementation of Directive 2014/104/EU of the European Parliament and of the Council of 26 November 2014 on certain rules governing actions for damages under national law for infringements of the competition law provisions of the Member States and of the European Union (Commission's 2020 Report) SWD(2020) 338 final, 1-2.

49 Courage (n. 47) para. 52.

50 Directive 2014/104/EU of the European Parliament and of the Council of 26 November 2014 on certain rules governing actions for damages under national law for infringements of the competition law provisions of the Member States and of the European Union [2014] OJ L 349/1.

51 Ibid., recital 6.

52 C-557/12 Kone and Others $v$ ÖBB-Infrastruktur $A G$ [2014] ECLI:EU:C:2014: 1317 , para. 21 and the case law cited therein.

53 Directive, recital 3. 
ments of the EU competition rules can obtain full compensation for the harm they have suffered. ${ }^{54}$ In chapter II of this book, the Directive's provisions are introduced in more detail and discussed to what extent the implementation of those rules have created a level playing field for competition damages actions in the EU.

The entry into force of the Directive and the implementation of its rules has undoubtedly led to a boost in damages actions. The Commission finds in its 2020 Report on the implementation of the Directive of 2020 that based on a review of some empirical studies that the number of damages actions in 2019 alone amounted to $239 .{ }^{55}$ This is a significant increase from the approximately 50 cases before the courts at the beginning of 2014. Moreover, the damages actions no longer concentrate on three Member States but instead have become much more widespread.

\section{B THE INTERPLAY OF PUBLIC AND PRIVATE ENFORCEMENT}

As explained at the beginning of this chapter, in the EU the competition enforcement regime is a mixed private and public enforcement system. Public authorities impose sanctions and punishments, mostly fines and in some Member States even criminal sanctions, ${ }^{56}$ against the infringer, whereas private parties enforce competition rules through tort remedies, namely compensation in the form of damages.

There exists a vast literature on the benefits and implications of a mixed enforcement system combining public and private enforcement. For example, Becker and Stigler (1974) argue that deterrence would be achieved more effectively if private individuals enforced the law. ${ }^{57}$ Wils (2003), on the other hand, does not see private enforcement as an effective enforcement mechanism and sees compensation as the sole goal of private actions. ${ }^{58}$ In particular, the optimal balance between the two enforcement regimes has been discussed

\footnotetext{
54 See also Directive, Article 3 and recital 6.

55 Commission's 2020 Report (n. 48) 4.

56 In some Member States (e.g., Austria and Germany) only some specific infringements such as 'bid rigging' are sanctioned under the criminal code. In Bulgaria, Estonia, Ireland, Malta, Romania, Slovakia and the UK, criminal sanctions exist for cartel infringements.

57 Gary S. Becker and George J. Stigler, 'Law Enforcement, Malfeasance, and Compensation of Enforcers' (1974) 3 Journal of Legal Studies 1-18.

58 Wouter J. P. Wils, 'Should Private Antitrust Enforcement Be Encouraged in Europe?' (2003) 26 World Competition 473-488.
} 
extensively in the academic literature ${ }^{59}$ and received particular attention in the political debate. ${ }^{60}$

The Impact Study, accompanying the White Paper of the Directive, reviewed the existing literature on the social welfare implications of a mixed enforcement system. ${ }^{61}$ Although much of the literature is based on the US system, and arguably the conclusions reached in analyses of the US system are not necessarily transferable to the EU regime, the findings of the report outline the general implications of a combination of public and private enforcement. The study found that in contrast to a single enforcement regime based solely on public enforcement, a mixed system increases complexity but the channels for scrutinising anticompetitive conduct multiply. Following the introduction of an effective private enforcement system, the detection of cartels is not only left to the Commission and NCAs but also private parties (e.g., a competitor, a downstream firm, a consumer or group of consumers) - who likely hold better information and can take a stand-alone antitrust damages action before a national court. ${ }^{62}$ This may lead to an increased enforcement of the competition rules but at the same time also allows private parties to strategically 'abuse' the competition rules for a different agenda. This opens the potential for a false positive judgment (type I error), i.e., a judgment wrongfully finding an infringement. Equally, the possibility of a false negative (type II error) exists where the national court wrongfully does not find an infringement.

As explained above, private enforcement in the EU predominantly takes the form of follow-on actions after the authority has already imposed a fine. This reality is also mirrored in the Directive's approach, which focuses nearly entirely on follow-on actions. In theory, the negative effects of a false positive judgment of the Commission or an NCA are potentially worse under the European mixed enforcement system because the undertaking against which the infringement decision was imposed may in addition to the fine also be subject to damages actions from purchasers or other parties.

The Impact Study finds that the impact of private enforcement on overall welfare can be mixed and is therefore not easy to determine. The authors note,

59 Gary S. Becker and George J. Stigler (n. 57) 1-18; William M. Landes and Richard A. Posner, 'The Private Enforcement of Law' (1975) 4 Journal of Legal Studies 1-46; A. Mitchell Polinsky, 'Private versus Public Enforcement of Fines' (1980) 9 Journal of Legal Studies 105-127. For an overview, see CEPS, EUR, and LUISS, 'Making Antitrust Damages Actions More Effective in the EU: Welfare Impact and Potential Scenarios' (2007) Final Report http://ec.europa.eu/competition/antitrust/ actionsdamages/files_white_paper/impact_study.pdf(Impact Study).

${ }^{60}$ An overview of the history of the debate is available at the DG Comp website $\mathrm{http}: / /$ ec.europa.eu/competition/antitrust/actionsdamages/index.html.

$61 \quad$ Impact Study (n. 59) 65ff.

$62 \quad$ Impact Study (n. 59) 66. 
however, that through a mixed system the probability that illegal actions are deterred increases, which in turn also leads to an increase in social welfare through the elimination of the deadweight loss resulting from non-competitive markets. Social welfare will likely not increase if the infringement is overturned by a national court, but the compensation of the victim's losses though a judgment awarding damages will lead to a welfare transfer, net of the costs of the trial. Type I errors of either the public enforcer or the national court can have a negative effect on social welfare by punishing welfare-enhancing conduct. Likewise, type II errors can legitimatise anticompetitive conduct which negatively effects society as a whole. ${ }^{63}$

The study concludes that what will determine the impact of the private enforcement is to what extent private actions serve the overarching goal of achieving optimal deterrence of anticompetitive conduct. ${ }^{64}$ The authors name three factors by which private enforcement can increase deterrence: (i) by increasing the detection rate, (ii) by increasing the prospective penalty after detection, and (iii) by ensuring more accurate fact finding.

(i) Detection rate: As noted above, if competition infringements are also enforced by private parties in addition to enforcement authorities, it will likely lead to an increase in the detection of infringements because they have better information concerning the illegal conduct available to them. By contrast, as explained at the beginning of this chapter, the EU public enforcement system has created its own tools, such as leniency programmes, to uncover cartels. In fact, the leniency programme has become the Commission's most important tool to detect cartels. Private enforcement will therefore only have a positive impact on deterrence if its impact on the detection rate is not outweighed by potentially negative effects on the detection tools of the public enforcement system. As mentioned before, private enforcement in the EU mainly means that private parties file a follow-on damages action after the infringement has already been detected by a public authority.

(ii) Increasing the prospective penalty after detection: An effect of damages actions in addition to the fine imposed by the competition authority is that it increases the overall costs of committing an infringement. Hence, the undertaking's expectation that it will face civil liability in addition to fines, once the infringement is uncovered, will make it less attractive for the undertaking to commit the infringement than without civil liability.

\footnotetext{
63 Impact Study (n. 59) 69-70.

64 Impact Study (n. 59) 70.
} 
On the other hand, an increase in civil liability can also make it less attractive to cooperate with competition authorities.

(iii) More effective fact finding: In theory, the victim of an infringement should have better information available about the infringement than the competition authority because it might be directly affected by the infringement or has a better understanding of the affected market. The Impact Study also finds that it is widely accepted in the economic literature that private parties possess better knowledge about an anticompetitive behaviour than public authorities and that it would be virtually impossible for the public authority to observe the market to obtain comparable information. ${ }^{65}$ In practice, private parties are, however, not necessarily better informed than public authorities. The study also notes that especially in cartel cases where the infringement is not evident, public authorities are better equipped to uncover the infringement using sophisticated tools. Again, the leniency programme is one of the competition authorities' most effective weapons to uncover cartels. In this context, and in its proposal for the Directive, the Commission explains that the reason for the introduction of the new disclosure rules lies in the information asymmetry problem, meaning that the necessary information for claimants to make their case is often unknown to them and in the hands of the infringers. This might be different in exclusionary abuse cases in which the abuse is more apparent from the behaviour of the dominant undertaking. An enforcement system with an optimal interplay between public and private enforcement must therefore ensure that the information-gathering tools available to competition authorities and victims are sufficient to uncover infringements.

Overall, a mixed enforcement regime requires a difficult balancing between the instruments of public enforcement and private enforcement to ensure that private actions do not jeopardise the effectiveness of the instruments of public enforcement or vice versa. The interplay between the two enforcement systems is optimal when the enforcement regime as a whole achieves optimal deterrence. The impact of the Directive on the EU enforcement systems needs therefore equally to be assessed based on the deterrence effect of the enforcement regime as a whole after the transposition of the Directive.

65 Impact Study (n. 59) 74; referring inter alia to Steven Shavell, 'Liability for Harm versus Regulation of Safety' (1984) 13 Journal of Legal Studies 357-374 and Joseph F. Brodley, 'Antitrust Standing in Private Merger Cases: Reconciling Private Incentives and Public Enforcement Goals’ (1995) 94 Michigan Law Review 1. 


\section{RESEARCH OBJECTIVES}

It follows from the discussion above that the question of whether the interplay between public and private enforcement is optimal should be determined based on the deterrence effect the enforcement regime achieves. It should be recalled from section A.III above that the Directive has two objectives, namely optimising the interaction between public and private enforcement of competition law and ensuring that victims of infringements can obtain full compensation for the harm they have suffered. Thus, the Directive's objective to optimise the interaction between public and private enforcement can be best measured in terms of the deterrence effect that the EU enforcement system together with Directive's provisions can achieve. In addition, the interplay between the enforcement system and the Directive's rules should also guarantee the victims' right to receive compensation for their losses caused by the competition law infringement. In order to ensure that the Directive's objectives are achieved, a difficult balancing act between deterrence of infringements and compensation of victims is required. This book addresses the balancing of these two objectives and studies to what extent the Directive's provisions will

(1) achieve deterrence of new infringements, and

(2) guarantee the right to full compensation of victims of competition infringements.

The Directive's two objectives are not mutually exclusive and neither should they be studied in isolation. As was already touched upon in the previous section, compensation of victims also contributes to the deterrence effect, as any increase in civil liability ultimately also raises the overall cost of violating the competition rules. At the other extreme, civil liability in addition to fines can create disproportionately high costs and thus result in over-deterrence.

The significance of private enforcement for deterrence has also been recognised by the CJEU. In Courage, the CJEU had already referred to the compensation of individuals (damages) as an instrument contributing to the effective enforcement of the competition rules by discouraging agreements or practices which distort competition. ${ }^{66}$ In Skanska, the CJEU relied explicitly on Advocate General Wahl's opinion and emphasised that 'actions for damages for infringement of EU competition rules are an integral part of the system for enforcement of those rules, which are intended to punish anticompetitive behaviour on the part of undertakings and to deter them from engaging in such

${ }_{66}$ Courage Ltd v Bernard Crehan (n. 47) para. 27. 
conduct' ${ }^{97}$ In his opinion, Wahl further expressed that actions for damages form an integral part of the competition enforcement system, which '(taken as a whole) aims primarily at deterring undertakings from engaging in anticompetitive behaviour' ${ }^{68}$ More recently, in Sumal, the CJEU elaborated on the role compensation plays in achieving the goals of the enforcement system. The Court states that "[b]eyond the compensation itself for the harm alleged, the establishment of [the right to seek compensation] contributes to the objective of dissuasion, which is at the heart of the [Commission's task]" and is "thus capable not only of providing a remedy for direct damage alleged to have been suffered by the person in question, but also indirect harm done to the structure and operation of the market, which was not able to reach full economic efficacy, in particular as regards benefits to the consumers concerned" ${ }^{69}$ It follows that the provisions of the Directive must be assessed against the objectives of private enforcement set out in the case law and during the legislative process, namely to compensate victims of competition infringements and to effectively integrate private and public enforcement in an overall enforcement system to deter other infringements.

It is not the aim of this book to study how every single provision of the Directive impacts on the EU enforcement system. Many provisions will have little or no effect other than encouraging private actions. Instead, this book focuses on three aspects for which the author considers optimisation to be crucial in order to achieve the Directive's two main objectives: the EU leniency programme, the methodology for setting fines for competition infringements, and the allocation of civil liability among joint infringers. It will be shown throughout this book that an increased attractiveness of damages claims and the corresponding increase of civil liability for competition infringers impacts these three instruments and in turn is likely to lead to negative effects on deterrence and compensation. The study will make concrete legislative proposals to overcome these negative effects in light of reconciling deterrence and compensation.

The analyses in this book contribute to the discussion on the shaping of an optimal enforcement regime in the EU and more specifically on the adjustments to the enforcement system that have become necessary following the implementation of the Directive. The legislator intended there to be a review of the impact of the Directive by the Commission by the end of 2020. However,

67 Case C-724/17 Vantaan kaupunki v Skanska Industrial Solutions Oy et al. [2019] ECLI:EU:C:2019:204, para. 45.

68 Case C-724/17, Vantaan kaupunki v Skanska Industrial Solutions Oy et al.[2019] ECLI:EU:C:2019:100, Opinion of Advocate General Wahl, para. 80.

69 Case C-882/19 Sumal S.L. v Mercedes Benz Trucks España, S.L. [2021] ECLI: EU:C:2021:800, para. 36. 
as will be shown in the next chapter, the rules transposed by Member States vary significantly as regards their temporal applicability. In other words, in many Member States it will still take years before the new rules will become applicable. Based on this lack of empirical evidence, the Commission concluded that by the end of 2020 it could not carry out a meaningful evaluation of the Directive. ${ }^{70}$ But the Commission also notes that there exists sufficient empirical evidence to show that the number of damages actions has significantly increased since the entry into force of the Directive. ${ }^{71}$ In line with this evidence, the working hypothesis of this book is that the number of damages actions and the civil remedies awarded will continue to rise in the coming years. Parts II-IV of this book analyse the implications of an increased civil liability on the EU leniency programme, the methodology for calculating fines, and the distribution of the liability among joint infringers.

Moreover, the analysis is limited to well-organised, hard-core, price-fixing cartels. It is assumed that such cartels are operated effectively in secrecy and are therefore difficult to discover. The rationale behind the focus on this particularly serious type of infringement is to examine the Directive's effectiveness in terms of its primary goal of deterrence. Admittedly, there are good legal considerations that justify not punishing to the maximum overall but reducing the sanctions for less serious infringements. ${ }^{72}$ The impact of less serious infringements, which may justify a deviation from the level of sanction of the optimal enforcement theory, goes beyond the scope of this analysis. The impact of the adjustments proposed in this book on other types of infringements, in particular abusive behaviour (Article 102 TFEU), should be developed in further research.

The analysis is based on the rational choice theory and does not include other moral or behavioural aspects. Some have argued that behavioural aspects should be included in the theory of deterrence. ${ }^{73}$ The underlying assumption of this study is that firms decide to participate in a well-organised hard-core cartel or to leave the same cartel on the basis of a cost-benefit analysis. Firms that go through the effort to put in place mechanisms to strengthen the organisation of a cartel (e.g., monitoring and punishment mechanisms) so that it can operate

Commission's 2020 Report (n. 48) 2.

Ibid.

72 See for example Harold Houba, Evgenia Motchenkova and Quan Wen, 'Legal Principles in Antitrust Enforcement' (2018) 120 Scandinavian Journal of Economics 859-893.

73 See for example Anthony Gray, 'Criminal Sanctions for Cartel Behaviour' (2008) 8 Queensland University of Technology Law \& Justice Journal 364; Christopher Harding, 'Cartel Deterrence: The Search for Evidence and Argument' (2011) 56 Antitrust Bulletin 345-376. 
effectively in secrecy are equally likely to have put in place decision-making processes that circumvent individual biases that affect the firms' profits. For those reasons, it is more likely that for those firms the possible consequences of enforcement are more important drivers of compliance than moral views. However, moral views are more relevant for individual informants blowing the whistle, which should be developed in further research. ${ }^{74}$

\section{METHODOLOGY}

Before the implications of the Directive can be analysed in terms of deterrence and compensation, it is necessary to define the terms 'deterrence' and 'compensation' and specify how both can be determined and measured for the purpose of analysing the effectiveness of EU competition law enforcement.

Private parties predominantly enforce competition rules by bringing actions for damages, which in turn, in most Member States, are claims under tort law. However, the goals of tort law do not necessarily coincide with the two objectives of the Directive. Compensation of victims for losses suffered due to an activity of the injurer (e.g., a negligent driver causes an accident) is not the central goal of tort law. In fact, tort law has turned out to be a rather expensive means of compensating harm, since it requires a well-functioning judicial system, which involves high costs. ${ }^{75}$ Insurance, on the other hand, is much cheaper, and a quicker system for compensating victims, and therefore, a victim's first-party insurance would be preferable over tort liability if the only goal were the compensation of victims. ${ }^{76}$ In the literature on the economic analysis of tort law, tort law's goals are described as threefold: the minimisation of primary accident costs (deterrence), secondary accident costs (optimal risk spreading and bearing), and tertiary accident costs (administrative costs) ${ }^{77}$

74 In April 2019, the European Parliament approved the Proposal for a Directive on the protection of persons reporting on breaches of Union law [2018] OJ L305/17.

75 Steven Shavell, Economic Analysis of Accident Law (Harvard University Press 2009) 263.

${ }^{76}$ Giuseppe Dari-Mattiacci, 'Tort Law and Economics' in Hatzis Aritides (ed.), Economic Analysis of Law: A European Perspective (Edward Elgar 2003).

77 Guido Calabresi, The Costs of Accidents: A Legal and Economic Analysis (Yale University Press 1970) 26ff. An additional goal referred to by Calabresi is justice, although he admits that justice is difficult to define:

The fact that what is unfair is easier to define than what is fair, like the fact that what is fair in one system may be unfair in another, indicates that it would be better to examine the requirements of accident cost reduction first and then to see how various untried methods and systems suggested by that goal compare in terms of fairness with the system we use today - how, in other words, they 
The main goal of tort law is to give the injurer appropriate incentives to refrain from an activity that harms the victim (i.e., incentives for optimal precautions). In other words, any person who engages in an activity creates externalities, which are the probability that others may suffer losses as a result of that activity. Tort law is an instrument for providing behavioural incentives to avoid such losses; that is, to internalise these externalities. As a result of the threat of being held liable under tort law, actors incorporate possible losses of others in their decision on how much care to take, and how often to engage in an activity. ${ }^{78}$ By taking more care or reducing the activity, the actor lowers the risk that the victim is injured and thus also the expected losses. However, it is the injurer who decides on the level of precaution or whether and how often to engage in an activity, and the injurer bears the costs of such a decision. The victim, on the other hand, benefits from the precautions taken by the actor to lower the risk of losses to the victim. Therefore, if the actor who bears the costs of the precaution also benefits from the decision, then he or she will take the optimal level of precaution. By contrast, when either costs or benefits are external, the decision will not take into account all the costs and benefits involved. Tort law internalises these externalities to optimise the level of precaution. ${ }^{79}$ An optimal activity is taken when the marginal benefits of reducing the activity level equal the marginal costs thereof (i.e., a reduction in the expected losses of the victim).$^{80}$ In other words, the actor will reduce the level of activity or take additional precautions until the total cost (e.g., the cost of precaution and expected accident costs) in doing so is equal to the victim's benefit. Hence, if the actor perceives the probability that a loss will occur to be low, the actor will take fewer precautionary measures. The reason is that tort law does not pursue the goal of absolute deterrence but the goal of relative deterrence through tort remedies. ${ }^{81}$ As Cooter and Ulen (2011) explain, 'tort law often aims to internalize costs, such as the risk of accidents. Once costs are internalized, actors are free to do as they please, provided that they pay the price'. ${ }^{82}$

comply with our general sense of fairness and whether they are more or less likely to create specific instances of injustice than the current system.

78 Louis Visscher, 'Tort Damages', in Gerrit De Geest and others (eds), Encyclopedia of Law and Economics (2nd edn, Edward Elgar 2009) 154.

79 Guiseppe Dari-Mattiacci (n. 76) 4.

80 Louis Visscher (n. 78) with reference to extensive literature.

${ }^{81}$ Francesco Parisi, Daniel Pi, Barbara Luppi and Iole Fargnoli, 'Deterrence of Wrongdoing in Ancient Law' (2014) 14 Minnesota Legal Studies Research Paper.

82 Robert D. Cooter and Thomas Ulen, Law and Economics (6th edn, Pearson 2011) 462. 
The goal of absolute deterrence is common in criminal law. Criminal law imposes sanctions (or punishments) and is different to compensation under tort law, which shifts the victim's costs of an activity to the actor. Sanctions in criminal law make the injurer worse off without directly benefitting the victim. ${ }^{83}$ In contrast to tort remedies, sanctions are tailored to the benefit of the infringer and the probability of detection. Equally, the EU enforcement regime of competition law is based on the infringer's gain from the competition rule infringement. The internalisation of external costs of an activity is not a proper means to deter infringements when the expected benefit of the activity outweighs the costs. In other words, a thief cannot be deterred by the requirement that he returns the stolen goods whenever he gets caught. For deterrence to be effective, the law must impose enough punishment so that the expected net benefit of the crime to the criminal is negative. ${ }^{84}$

In competition law, the assessment of optimal enforcement was mostly influenced by the seminal work of Gary Becker, who applied the rational choice model to law enforcement. ${ }^{85}$ Becker assumes that undertakings choose to commit an infringement only on the basis of the expected utility, taking into account the gain (e.g., higher profits) and the probability and level of sanctions it will then face. Thus, the underlying logic is that undertakings act rationally, balance the costs and benefits of their conduct, and abstain from a certain conduct if the expected costs exceed the potential gains. Following Becker's optimal enforcement theory, the optimal penalty for cartels is equal to the deadweight loss plus the wealth transfer to the cartel (or other undertakings) from the victims. ${ }^{86}$ However, when 'the enforcement costs are positive and the probabilities of detection and punishment are less than perfect, optimal penalties should, according to the optimal deterrence model, exceed the social (efficiency) cost of the violation so as to correspond to the efficiency loss caused'. ${ }^{87}$ For deterrence to work, the minimum sanction must be equal to the expected gain from the infringement multiplied by the inverse of the probability that the infringement will be detected and the penalty effectively

\section{Cooter and Ulen (n. 82) 459-460.}

84 Ibid.

85 Gary S. Becker, 'Crime and Punishment: An Economic Approach' (1968) 76 Journal of Political Economy 169. Becker's original analysis was adapted to antitrust law enforcement by William M. Landes, 'Optimal Sanctions for Antitrust Violations' (1983) 50 University of Chicago Law Review 652-678.

${ }_{86}$ Ioannis Lianos, Peter J. Davis and Paolisa Nebbia, Damages Claims for the Infringement of EU Competition Law (Oxford University Press 2014) 7.21.

87 Ibid.; see also Jindrich Kloub, 'White Paper on Damage Actions for Breach of the EC Antitrust Rules: Plea for a More Holistic Approach to Antitrust Enforcement' (2009) 5 European Competition Journal 528-529. 
imposed. In other words, the sanction must render the expected gain from the infringement equal to zero.

As shown above, the preliminary goal of both tort and competition law is deterrence by setting incentives in a way that maximises total welfare. An optimal enforcement regime deters by alleviating the 'moral hazard' problem resulting from the divergence between the infringer's incentives and the socially desirable incentives.$^{88}$ In an enforcement regime that is heavily reliant on public authorities to detect and sanction infringements, deterrence is largely dependent on the effectiveness of the public enforcement system. In fact, in an enforcement regime that has deterrence as its sole goal, public enforcement might achieve deterrence more effectively. ${ }^{89}$ At the same time, at least in the law \& economics literature, the primary goal of tort law is perceived to be the deterrence of socially undesirable losses by providing behavioural incentives to avoid such risks of losses. Thus, in a mixed public and private enforcement regime such as the EU competition regime, two fields of law primarily aim at and contribute to deterrence of socially undesirable losses. Both regulate the behaviour of individuals by setting incentives to maximise total welfare. As a result, the efficiency of a mixed enforcement system such as the EU competition regime must be assessed by taking into account the behavioural incentives set by the administrative fines as well as tort remedies. For that reason, this book studies the deterrent effect of the interplay of the public enforcement system and the private enforcement system under the Directive's rules based on Becker's optimal deterrence model. ${ }^{90}$

\section{Compensation}

In contrast to the objective of deterrence, public enforcement is not well placed to achieve the Directive's objective of corrective justice, namely the compensation of victims. First, victims have better information on the harm they suffered, particularly because the information necessary for the estimation of the harm generally rests with the victim. ${ }^{91}$ Second, the proceeds from the public

\footnotetext{
88 Ioannis Lianos, Peter J. Davis and Paolisa Nebbia (n. 86) 7.18.

89 See for example Wouter P. J. Wils, 'Should Private Antitrust Enforcement Be Encouraged in Europe?' (2003) 26 World Competition 473-488.

90 It should be noted that the optimal sanction will be lower for risk-averse firms than for risk-neutral firms. This study assumes - as a general rule - that firms are risk neutral, which means that deterrence will only be effective if the expected sanction exceeds the gain.

${ }_{91}$ For example, a comparison of the actual prices with the counterfactual prices requires information on the actual prices the victim has paid (including rebates and discounts) prior to, during, and after the infringement as well as the turnover and products that were purchased during that period.
} 
authority's sanctions are not distributed to the victims but stay with the state. Public enforcement redistributes gains away from the infringer, which may promote the distributive justice objective but does not facilitate the Directive's goal of corrective justice. ${ }^{92}$ The transfer of wealth from the infringer back to the victim is better achieved through tort law, assuming that courts estimate the damage with sufficient accuracy. As discussed above, insurances are generally a more efficient means to compensate victims, but because insurance is not available for victims of competition infringements, tort remedies - assuming there is a functioning court system - are the second-best alternative to compensate victims. Thus, the Directive's objective of compensation of victims can only be achieved through private enforcement. For that reason, the incentives to deter competition infringements in the mixed public and private enforcement regime in the EU must ensure victims' right of full compensation through tort remedies. This study examines the effectiveness of the Directive's provisions in light of the deterrence objective as an efficiency requirement as well as their effectiveness in terms of ensuring the victims' right to full compensation. As compensation of victims in competition cases will only be achieved through tort remedies, the Directive's goal of compensation must prevail. In other words, this book studies how the Directive's rules, sanctions, and tort remedies interplay in terms of regulating incentives to achieve deterrence while simultaneously guaranteeing that tort remedies can fully compensate victims.

Admittedly, the meaning of full compensation is not straightforward. The ability to claim compensation might be limited for legal reasons, such as in a fault-based tort system in which victims also need to prove fault of the infringer. Equally, other legal instruments, such as foreseeability or adequacy to limit the but-for test for establishing a causal relationship between the infringement and the harm, prevent the compensation of the entire harm. The definition of losses that can be compensated depends on the legal rules of the individual jurisdiction. It follows from the case law of the CJEU that anyone who has suffered harm caused by an infringement of competition law should be able to claim compensation for actual loss (damnum emergens), for gain of which that person has been deprived (loss of profit or lucrum cessans), plus interest.

As discussed above, tort remedies should generally provide full compensation to the victims because only then will the injurer internalise all negative externalities and tort remedies that effectively deter wrongdoings. ${ }^{93}$ The goal of prevention of an infringement requires that the expected costs of an infringement are at least equal to the gains from the infringement. This sug-

92 See also Ioannis Lianos, Peter J. Davis and Paolisa Nebbia (n. 86) 7.40.

93 Louis Visscher (n. 78) 5. 
gests that compensation should be based on the gains of the infringer. Polinsky and Shavell $\left(1994^{94}\right)$ argue instead that compensation based on the harm is a better proxy because if damages are based on the infringer's gain and courts underestimate the gain, the incentives for the injurer are inadequate to prevent the infringement.

In competition cases, where firms collude to artificially increase prices (price fixing cartels) above the market level in order to generate higher profits, purchasers from the colluding firm will have to pay higher prices for the cartelised goods which increases their costs (i.e., the overcharge). In markets where firms face a downward-sloping demand curve, demand decreases where prices increase. This means that the increased cartelised price will be above the reservation prices of some customers. Therefore, in parallel to the economic theory of monopolies, ${ }^{95}$ the quantity of products supplied will be less than that which would be supplied in a competitive market. In economic terms, the increased cartelised price creates a loss of consumer surplus that is referred to as the deadweight loss. ${ }^{96}$ Hence, the increased cartelised price or in turn a reduction of output leads, on the one hand, to a harm in terms of an overcharge for purchasers from the cartel and, on the other hand, to a reduction of consumer welfare for those customers with reservation prices below the cartelised price.

In addition, if as a result of the increased cartelised price the (direct) purchaser also increases the price of her products, i.e., if the direct purchaser is able to pass on the overcharge to the next level on the supply chain, the demand of indirect purchasers will equally decrease. Thus, where direct purchasers can pass on the overcharge, they will suffer from an output effect ${ }^{97}$ in terms of reduced demand by indirect purchasers. This translates into a loss of profit suffered by direct purchasers due to the reduced sales resulting from passing-on. ${ }^{98}$ The output effect at all levels of the supply chain can be calculated relatively easy by multiplying the experienced reduction in sales with the

94 A. Mitchell Polinsky and Steven Shavell, 'Should Liability Be Based on the Harm to the Victim or the Gain to the Injurer?' (1994) 10(2) Journal of Law, Economics, \& Organization 427-437.

95 Simon Bishop and Mike Walker, The Economics of EC Competition Law (Sweet \& Maxwell 2010) 2-013.

96 See Chapter 6, D.II for a more detailed explanation of the deadweight loss.

97 The Commission also refers to it as the 'volume effect' in its Guidelines for national courts on how to estimate the share of overcharge which was passed on to the indirect purchaser [2019] OJ C267/07.

98 Ibid. See also Franziska Weber, 'Tackling Pass-On in Cartel Cases: A Comparative Analysis of the Interplay between Damages Law and Economic Insights' (2020) 16 European Competition Journal 570-594. 
profit margin that the purchaser would have had per unit in the situation but for the infringement.

For the purpose of corrective justice, the wealth transfers that need to be corrected (compensated) are therefore the overcharge that was either paid by the direct or indirect purchasers, the output effect if the direct purchaser was able to pass on the overcharge, and the losses that result from the loss of consumer surplus. Thus, the right to full compensation must ensure that direct purchasers can claim compensation for the overcharge they had to pay because of the cartelised price, i.e., compensation for the actual loss (damnum emergens), and in cases of passing-on of the overcharge to indirect purchasers, the loss in profit due to the output effect, i.e., compensation for loss of profit (lucrum cessans). Moreover, it must be ensured that other claimants that have suffered actual loss or loss in profit as a result of the deadweight loss caused by the increased cartelised price are not hindered from claiming compensation.

For the purpose of the analysis in this book, the full compensation refers to the compensation for the overcharge paid by direct and/or indirect purchasers. However, it must nevertheless be ensured that victims have the right to claim compensation for the output effect ${ }^{99}$ in cases of passing-on and other losses in relation to the loss in consumer surplus. The methodology for this study is therefore to test whether the Directive's provisions together with the administrative fines set adequate incentives not to enter into a cartel without jeopardising victims' ability to recover at least the overcharge (plus interest). ${ }^{100}$ Since in this book's analyses the overcharge that was paid by the victim constitutes the illicit gain of the cartelist as well as the victim's harm, the terms harm and gain are often used interchangeably for simplicity and better readability.

\section{The problem of over-enforcement}

An enforcement regime in which sanctions and tort remedies are imposed for the same violation also poses the risk of resulting in an excessive level of enforcement, also referred to as 'over-deterrence'. Over-deterrence creates inefficiencies because it creates significant costs. Lianos et al. (2015) list seven types of costs that may result from over-deterrence, namely the additional cost of law enforcement may be higher than the cost that the additional anticompetitive practice deterred would have imposed on society; as a result

99 This study will specifically consider the output effect only where it is necessary for the analyses of the proposed adjustment to the fining methodology in Chapter 7.

100 If the injurers were not obliged to pay interest for the period the victims were deprived of the amount of the overcharge, victims would not be fully compensated; see Steven Shavell, Economic Analysis of Accident Law (Harvard University Press 2009) 141. 
of high sanctions and damages, firms will spend a disproportionate amount of resources to ensure compliance; where damages are awarded beyond the harm that was suffered, claimants may have an incentive to bring 'dubious' claims; an excessive fine may lead to the insolvency of the undertaking, which may have negative welfare effects if it excludes an effective competitor; excessive fines may affect shareholders and stakeholders who were not aware of the illegal conduct; high fines and damages may deter efficient commercial practice; and enforcement errors will become costly in a system with high sanctions or damages. ${ }^{101}$ As explained in section B above, enforcement errors may be of two sorts: the enforcement body wrongly concludes that there is an infringement (false positive or error type I) or it falsely concludes that there was no wrongdoing and does not punish an infringement (false negative or error type II). ${ }^{102}$ Admittedly, cartels are in very rare cases welfare enhancing, and it is therefore unlikely that the cost of enforcement errors for society will be particularly high. This is particularly true for price-fixing cartels that cause an illicit overcharge, which is the type of infringement the analysis in this book focuses on. Nevertheless, if fines/damages are disproportionately high and it is not as obvious for firms, as it is for object types of infringements, to ascertain whether authorities consider an efficient cooperation between the firms to be legal, it is likely that the firms will refrain from efficient cooperation. Thus, over-deterrence is less likely to also deter obvious legal conduct but less obvious and potentially efficient conduct in the 'grey zone'. For example, assume that engineers from competing firms meet to exchange ideas for new technologies for ways to move towards more sustainable production methods. If sanctions are high and there is a risk that the enforcement body will conclude that such an exchange of information is anticompetitive, the engineers will likely not meet at all. ${ }^{103}$ The social costs of deterring more sustainable manufacturing in the industry is certainly higher than the elimination of a potentially anticompetitive (not price relevant) information exchange. Lianos et al. (2015) conclude that there can be over-deterrence in two instances, namely,

if (i) the sanctions are larger than the cost to society (e.g., overcharge, harm to innovation, reduction of quality, and consumer choice) due to the violation divided

\footnotetext{
101 Ioannis Lianos, Peter J. Davis and Paolisa Nebbia (n. 86) 7.45ff.

102 Ioannis Lianos, Peter J. Davis and Paolisa Nebbia (n. 86) 7.48.

103 The exchange of information between competitors can amount to an infringement of competition rules even where those exchanges are not ancillary to or dependent on an existing cartel agreement if the information exchange artificially increases transparency in the market, facilitates coordination between competitors and results in restrictive effects on competition; see Guidelines on the applicability of Article 101 of the Treaty on the Functioning of the European Union to horizontal co-operation agreements [2011] OJ C11/01, para. 65.
} 
by the probability of the violators being found guilty and (ii) the marginal cost of sanctioning cartels is larger than the marginal revenue to society from eliminating them. ${ }^{104}$

Hence, there is a possibility that in a mixed private and public enforcement regime such as the EU, in which private enforcement has only recently come into effect and on top of an existing public enforcement system designed for deterrence, the combined punishment (fines + damages) can result in over-deterrence. The same risk applies to situations of overcompensation where courts award damages exceeding the harm that was caused. Although the risk of over-deterrence is low in hard-core cases (e.g., price-fixing cartels) in which under-deterrence is probably more likely because of the low probability of detection, this study sporadically and where necessary discusses the problem of over-deterrence for conduct in the 'grey zone'.

In addition, other criteria are taken into account where necessary for the analysis, namely administrative efficiencies and distributive justice goals. It should be noted that a rule may achieve full compensation and sufficient deterrence, but to do so it might become so complex that its use overburdens administrative bodies and ultimately hampers effective enforcement. For that reason, where necessary, the legislative proposals in this study are also assessed in terms of their usability in practice (administrative efficiency). Equally, the proposals in this study are adjusted for distributive justice considerations where appropriate and necessary.

\section{E STRUCTURE OF THE BOOK}

This book is composed of four parts and seven chapters. Each part of the book focuses on a different aspect of the research question.

Part I provides the background for the analysis in this book. Chapter 2 describes the legislative process that ultimately led to the entry into force of the Directive before outlining the Directive's provisions in more detail. The remainder of the book then examines more closely those provisions that are relevant for the respective analysis. A particular focus of the chapter lies on the implementation of the Directive's provisions into national laws. The aim is to show that despite the Directive's objective to create a level playing field in Europe, there still exists some substantial divergence between Member States. It is important to be aware of this divergence because the analyses in the following parts of the book focus on the Directive's rules, assuming they are applied universally across Europe. The effectiveness of the adjustment to

104 Ioannis Lianos, Peter J. Davis and Paolisa Nebbia (n. 86) 7.55. 
the enforcement regime proposed in this book might therefore be affected by different rules applicable between Member States. The analyses in the remaining parts of the book refer to some national rules that are likely to influence the results of the study, by way of example.

Part II addresses an issue that the Directive has intentionally left to national courts, namely the allocation of civil liability among joint infringers. Chapter 3 contrasts the distribution of liability in Europe with the situation in the US (no-contribution rules). It outlines the debate in the US surrounding the no-contribution rules, in particular the objections that have been raised against excluding contribution and arguments in favour of deterrence. Chapter 4 picks up, inter alia, on those considerations raised in relation to the no-contribution rule and examines different methods for the quantification of relative responsibility. It proposes a method for determining the contribution that satisfies, on the one hand, the conditions set out in the Directive and scores best in terms of deterrence. Chapter 5 then focuses more closely on how the allocation rule proposed in the previous chapter might need to be adjusted according to the roles of the infringers in the cartel. It reviews the Commission's practice in adjusting the fines for mitigating and aggravating factors and proposes a methodology that adjusts the share of the contribution accordingly.

Part III turns to the effects of the Directive on leniency incentives. Although the Directive attempts to protect leniency recipients by protecting leniency statements from disclosure, the analysis in Chapter 6 shows that the additional civil liability is likely to have a stabilising effect on well-operated cartels. It shows that firms have an incentive to reveal the infringement and to cooperate even in cartels with a low detection rate if immunity/leniency recipients are offered immunity or reductions from the civil liability proportionate to the reductions from fines granted to immunity/leniency recipients. Furthermore, it shows that the proposed proportionate damages alternative is better equipped to reconcile the goal of compensation and deterrence compared with the current approach under the Directive.

Part IV examines the overall impact of damages actions on the calculation of fines. A potential rise of civil liability following the implementation of the Directive, in addition to fines, is likely to create an overall level of sanctions that is no longer proportionate to the harm and likely to create over-deterrence, which may reduce welfare-enhancing transactions. Chapter 7 proposes a new methodology for the calculation of fines that reconciles fines and damages irrespective of how private enforcement may develop in the future. The proposal takes the potential civil liability into account for the calculation of fines. It is shown that the proposed methodology scores better in terms of deterrence than the current situation, while guaranteeing the right to full compensation. 